\title{
ORGANIC MATTER COMPOSITION RELATED TO METHANE EBULLITIVE FLUX OF AN URBAN COASTAL LAGOON, SOUTHEASTERN BRAZIL
}

\author{
Alessandra da Fonseca Viana ${ }^{\mathrm{a}, *,(\mathbb{C}}$, Marco Aurélio dos Santos ${ }^{\mathrm{a}}$, Marcelo Corrêa Bernardes ${ }^{\mathrm{b}}$ and Marcelo Amorim $^{\mathrm{a}}$ \\ anstituto Alberto Luiz Coimbra de Pós-Graduação e Pesquisa de Engenharia, Universidade Federal do Rio de Janeiro, 21941-450 \\ Rio de Janeiro - RJ, Brasil \\ 'Departamento de Geoquímica, Universidade Federal Fluminense, 24020-141 Niterói - RJ, Brasil
}

Recebido em 25/04/2019; aceito em 04/06/2019; publicado na web em 26/06/2019

\begin{abstract}
In 2016, Brazil emitted 18.25 Tg of methane. Some of these emissions occur through continental aquatic ecosystems, locations of fate and accumulation of organic and inorganic matter. Thus, the aim of this study is to evaluate the origin of organic matter in Rodrigo de Freitas Lagoon, an eutrophic, coastal and chocked lagoon in Rio de Janeiro, Brazil, through the determination of $n$-alkanes and sterols compounds in the upper two centimeters of sediment and compare these data with methane ebullitive flux. The concentrations of $n$-alkanes varied between 2.43 and $25.82 \mu \mathrm{g} \mathrm{g}{ }^{-1}$. C29 was predominant compound in most sites, but also with important petrogenic source evidenced by the occurrence of Unresolved Complex Misture. The total concentration of sterols ranged from 2.76 to $56.01 \mu \mathrm{g} \mathrm{g}^{-1}$. $\beta$-sitostanol was the most abundant compound and coprostanol was the most relevant at the sites under influence of domestic effluents. $\mathrm{CH}_{4}$ ebullitive flux averaged $199 \mathrm{mg} \mathrm{m}^{-2} \mathrm{~d}^{-1}$ in the dry period and $9.3 \mathrm{mg} \mathrm{m}^{-2} \mathrm{~d}^{-1}$ during the wet season. We conclude that the organic matter reaching Rodrigo de Freitas Lagoon through the rivers discharge added or enriched with irregular sewage input and petroleum derivates are the main source of eutrophication and generate higher methane emissions to the atmosphere.
\end{abstract}

Keywords: $n$-alkanes; sterols; methane; ebullitive flux; coastal lagoon.

\section{INTRODUCTION}

Methane $\left(\mathrm{CH}_{4}\right)$ concentrations in the atmosphere have been significantly increasing in the last and the present century. It has been recently reported that, compared to pre-industrial period, methane levels were $150 \%$ and $257 \%$ higher in 2011 and 2016 , respectively. ${ }^{1,2}$ About $60 \%$ of the global methane emissions are of anthropic origin, such as those produced in landfills during activities linked to rice farming, burning of fossil fuels and livestock, with estimated emissions around $352(340-360) \mathrm{TgCH}_{4} \mathrm{yr}^{-1} .{ }^{3}$ On the other hand, non-anthropic emissions produced in continental aquatic ecosystems, such as lakes, coastal lagoons and ponds were up to 120 (60-180) $\mathrm{TgCH}_{4} \mathrm{yr}^{-1}$. 3,4

In this context, coastal lagoons are characterized by restricted connection to the sea and a long water retention time, which produces sites of fate and accumulation of organic and inorganic matter, ${ }^{5-7}$ whose carbon content reaches the environment to be degraded and emitted into the atmosphere..$^{8-10}$ The metabolization of carbon in anoxic freshwater sediments contributes to high methane emissions. ${ }^{11,12}$ In addition, these lagoons generally undergo anthropic influences, such as the discharge of urban and industrial waste, which accelerates the process of eutrophication, inducing an higher oxygen consumption and anaerobic decomposition in the sediments and consequently increasing the $\mathrm{CH}_{4}$ release into the atmosphere. ${ }^{13}$

To understand the origin of organic matter present in these systems and to obtain information about their source, transport and fate, some lipidis biomarkers have been determined, such as $n$-alkanes and sterols. ${ }^{14}$ Lipids are insoluble in water, but can be extracted by solvents that dissolve fats. Its chemical composition can be used to assess organic matter origin, since the compounds are specific to their source, and their molecules are highly preserved in aquatic environment. $\mathrm{N}$-alkanes are dominant constituents among biogenic hydrocarbons and important biomarkers because of their resistance

*e-mail: fviana.ale@gmail.com to degradation. ${ }^{15}$ They originate from various sources, such as marine organisms, terrestrial plants, anthropic activities and petrogenetic contamination, being differentiated by the distribution pattern of their compounds in the samples. ${ }^{16-18}$ The lipid group of sterols has also been used as biomarker. Most sterols are poorly soluble in water, hard to be anaerobically degradaded and, consequently, accumulate in marine sediments. ${ }^{19}$ Sterols can be good indicators of domestic effluents present in aquatic environments ${ }^{20}$ and have been used in several studies about coastal regions. ${ }^{21-23}$ In addition, they can help to characterize the organic matter sources distinguishing plankton, higher plants, fungi and bacterial activity. ${ }^{24-26}$

The importance of coastal lagoons as potential ecosystems for emission of greenhouse gases is related to the accumulation of different forms of organic carbon. Thus, the present study aimed to evaluate the origin of organic matter in an urban, coastal and eutrophic lagoon located in the city of Rio de Janeiro / Brazil, Rodrigo de Freitas Lagoon, through the determination of $n$-alkanes and sterols forms found in the upper two centimeters of the sediment, as well as to compare these data with methane emission from ebullitive flux.

\section{Study area}

The Rodrigo de Freitas Lagoon is located in the city of Rio de Janeiro under the coordinates $22^{\circ} 57^{\prime} 22^{\prime \prime}$ to $22^{\circ} 58^{\prime} 09^{\prime \prime} \mathrm{S}$ and $43^{\circ} 11^{\prime} 09^{\prime \prime}$ to $43^{\circ} 13^{\prime} 03^{\prime \prime} \mathrm{W}$ (Figure 1). According to the Contingency and Monitoring Plan for the Rodrigo de Freitas lagoon, the site has a water surface of $2.2 \mathrm{~km}^{2}$, average depth of $2.8 \mathrm{~m}, 7.8 \mathrm{~km}$ of perimeter, water volume of approximately $6,200,000 \mathrm{~m}^{327}$ and five residential districts with population of 157,282 inhabitants in the surroundings. ${ }^{28}$

This is considered a choked lagoon ${ }^{30}$ because there is a single sea connection, the Jardim de Alah Channel with $800 \mathrm{~m}$ long and 10-18 meters wide, which is mostly silted. Thus, water exchange is very inefficient, which results in an accumulation of suspended particles and organic matter inside the lagoon arising from the rivers. ${ }^{31}$ 


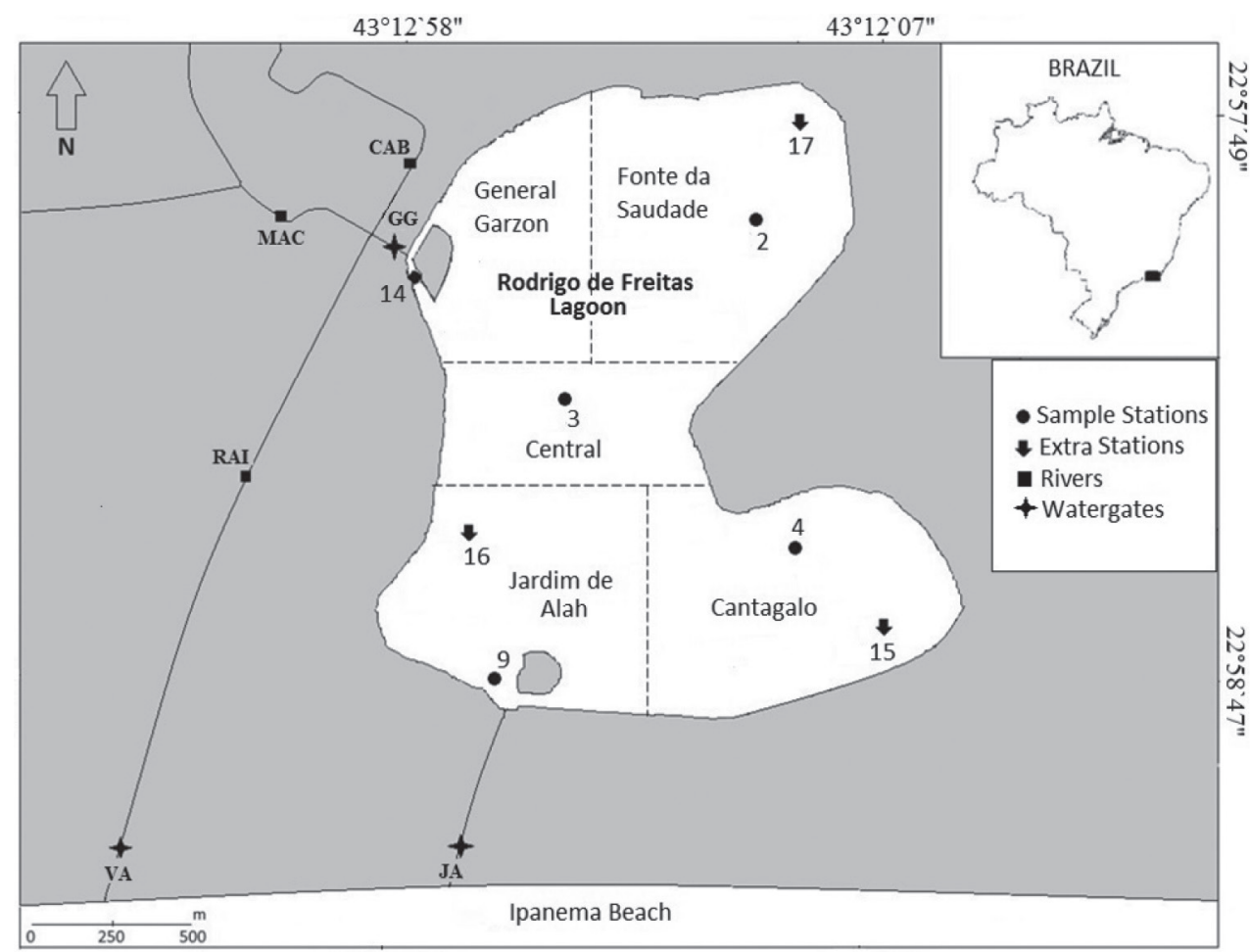

Figure 1. Map of Rodrigo de Freitas Lagoon showing collection points (2, 3, 4, 9, 14), extra collection points in the rainy season (15, 16, 17), rivers that flow into the Lagoon (CAB: Cabeças River, MAC: Macacos River, RAI: Rainha River), dams comprising the hydric system (GG: General Garzon, VA: Visconde de Albuquerque, JA: Jardim de Alah) and regions names: Fonte da Saudade, Central, Cantagalo, Jardim de Alah and General Garzon. Adapted from Oliveira ${ }^{29}$

The water catchment area is about $32 \mathrm{~km}^{2}$. The Cabeça and Macacos Rivers rise in the Tijuca National Park - a conservation unit entirely located in the city of Rio de Janeiro - and flow into the Rodrigo de Freitas Lagoon through a single channel. The Rainha River rises in the Serra da Carioca, name given to the mountain range that covers the city of Rio de Janeiro. These rivers rise in regions covered by dense Atlantic Forest vegetation, but pass through urbanized areas receiving huge loads of domestic effluents. The regional water system also includes three flood gates: the first one located in the drainage of Cabeça and Macacos Rivers, in General Garzon street; the second one located in the Rainha river, on the Visconde de Albuquerque avenue; and the third one located on the channel connecting the sea, the Jardim de Alah Channel.

These gates remain mostly closed, avoiding the constant depletion of the rivers that are great sources of organic matter and sediment for the lagoon..$^{27}$ They are sporadically opened in times of rains to control the water column level and tides influence. The lagoon is eutrophic mainly due to the influence of domestic effluents, ${ }^{32}$ and its larger deposits of organic inputs and nutrients result from the inflows brought on by heavy rains that leach the soil, drains through pluvial systems and possibly receive the sewage discharge. ${ }^{33}$

\section{EXPERIMENTAL}

The collections occurred in two periods at Rodrigo de Freitas Lagoon: April 2016, during a month of low rainfall characterizing the dry season (D); and December 2016, period of higher precipitation characterizing the wet season (W). Five collection sites (Table 1; Figure 1) were set to represent different regions of the lagoon and to evaluate the locations near the discharge of Cabeça and Macacos Rivers, the Jardim de Alah channel and sites with a history of sewage in the reports of Municipal Department of Environment. Collections always occurred in the same period (between 9 a.m and 4 p.m), respecting the same site order.
Three sites (15, 16 and 17) were included in the second collection performed in December due to dredging operations in the lagoon between June and July to host the Rio de Janeiro Olympic and Paralympic Rowing and Canoeing events. In sites 16 and 17, starting and finishing rowing places, sediment had been dredged and placed at site 15 .

During sampling, the sediment was collected with a Van-Veen dredger and the upper two centimeters of sediment were used for granulometry, organic matter, sterols and $n$-alkanes analysis. Granulometric analysis was performed only in the first collection (April 2016), using the Malvern Mastersizer 2000, a laser diffraction equipment used to evaluate particle size distribution, mostly for fine sediments and data were analyzed by the software Gradistat 6.0 using the screening methodology for thicker sediments. Particle size fractions were determined according to the Wentworth scale. ${ }^{34}$ The limits of these classes were slab (> $256 \mathrm{~mm})$, pebble $(256-64 \mathrm{~mm})$, gravel $(64-4 \mathrm{~mm})$, granule $(4-2 \mathrm{~mm})$, sand $(2-0.062 \mathrm{~mm})$, silt $(0.062-0.004 \mathrm{~mm})$ and clay $(<0.004 \mathrm{~mm})$.

Total organic matter was determined by the gravimetric method, available in the ABNT Standard - NBR $10664 .{ }^{35}$ Briefly, an empty capsule previously placed in the muffle at $550 \pm 50^{\circ} \mathrm{C}$ for 1 hour, was used to weighed 25 to $50 \mathrm{~g}$ of sample. Then, sample in the capsule was placed in an oven between 103 to $105^{\circ} \mathrm{C}$ for at least 12 hours and weighed with an accuracy of $10 \mathrm{mg}$. The total residue was given by the following expression: $\%$ total residue $=\left(\mathrm{m}_{10} \times 100\right) / \mathrm{m}_{\mathrm{g}}$, where $\mathrm{m}_{10}=$ mass of the total residue in grams and $\mathrm{m}_{\mathrm{g}}=$ mass of the sample in grams.

Gas emission was calculated through the ebullitive flux, as detailed by Brasil, ${ }^{36}$ using "inverted" funnels (Figure 2). Each funnel covered the area of $0.69 \mathrm{~m}^{2}$ and its apex was connected to a collection flask. One or two funnels were installed at the sites 2, 3, 4, 9 and 14 , which were tied together with one tip being attached to anchors to ensure the funnels remain in the correct depth. After 24 hours, an aliquot of the gas was withdrawn and taken for gas chromatographic 
analysis. Ebullitive flux was calculated by the following procedure, according to Brasi ${ }^{36}$ and adapted from UNESCO $:^{37}$

Methane: Ebullitive emission $\left(\mathrm{mg} \mathrm{m}^{-2} \mathrm{~d}^{-1}\right)=\left(\right.$ Factor for $\mathrm{CH}_{4} \times$ $\mathrm{P}[\mathrm{mmHg}] \times \% \mathrm{CH}_{4} \times$ Vol. Col. [mL] $/(\mathrm{T}[\mathrm{K}] \times \Delta \mathrm{t}[\mathrm{h}] \times$ Quantity of Funnels).

Considering: $\mathrm{CH}_{4}$ Factor $=0.164541 ; \mathrm{P}[\mathrm{mmHg}]=$ Atmospheric pressure in the laboratory; $\% \mathrm{CH}_{4}=$ Result of chromatographic analysis of methane in \%; Vol. Col. $[\mathrm{mL}]=$ Volume of gas collected by the funnel. $\mathrm{T}[\mathrm{K}]=$ Temperature in the laboratory; $\Delta \mathrm{t}[\mathrm{h}]=$ time that the funnels were inside the water.

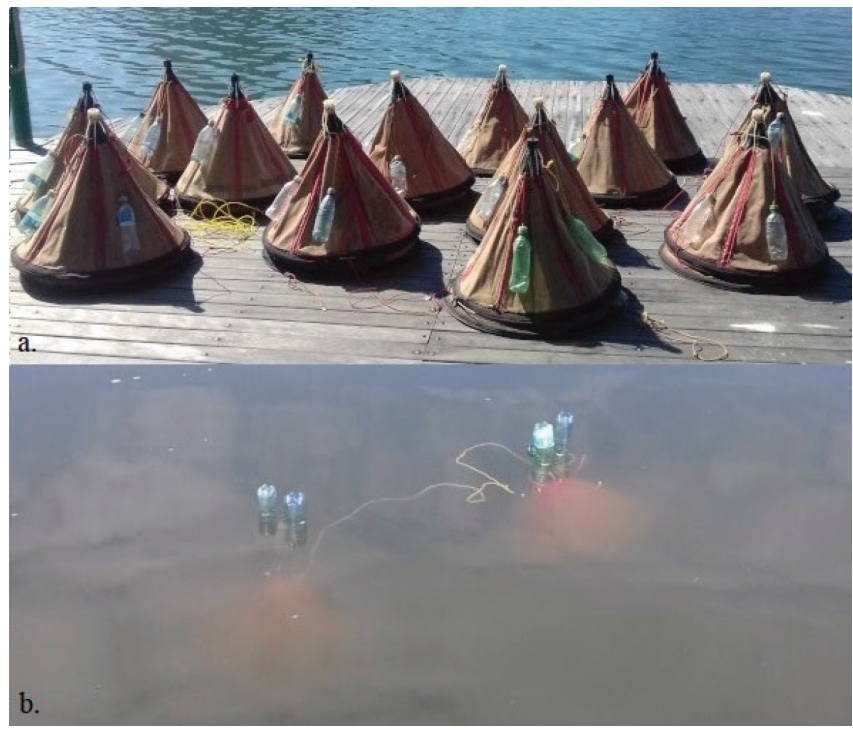

Figure 2. "Inverted" funnels used to collect methane ebullitive flux. a. funnels before being placed in the water; $b$. two funnels tied together in the water attached to anchors to be placed in the correct depth and the apex connected to a collection flask

Gas analysis were performed using a Shimadzu gas chromatography equipment, model GC 2014. Methane was quantified with a flame ionization detector (FID). The calibration was performed

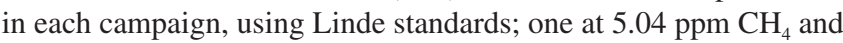

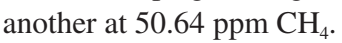

Sterol and $n$-alkane analysis was performed according to Wakeham and Canuel, ${ }^{38}$ with modifications. Initially, sediments were oven dried at $50{ }^{\circ} \mathrm{C}$, homogenized and weighed. Subsequently, approximately $3 \mathrm{~g}$ were subjected to total extraction through ultrasonic baths and dichloromethane/methanol treatments for 15 minutes at $35{ }^{\circ} \mathrm{C}$ in the following order: dichloromethane $100 \%$; dichloromethane:methanol $1: 1$ and then 1:2. After each solvent, samples were centrifuged and the supernatant collected. All supernatant was placed in a rotary evaporator to reduce the volume to $\sim 1 \mathrm{~mL}$, then transferred to a vial with heptane, dried under nitrogen gas and identified. Afterwards, extracts were fractionated on a silica column to obtain the fractions relative to $n$-alkanes and sterols. The total lipid extract was resuspended with $1 \mathrm{~mL}$ of heptane and transferred to the top of a chromatographic column made with a silica gel-filled Pasteur pipette (calcined, activated at $120^{\circ} \mathrm{C} / 24 \mathrm{~h}$ and deactivated with $5 \%$ distilled water) in heptane. $2.0 \mathrm{~mL}$ of heptane was added to obtain fraction $\mathrm{F} 1 ; 2.0 \mathrm{~mL}$ of heptane $+50 \%$ toluene to $\mathrm{F} 2$ fraction; $2.5 \mathrm{~mL}$ of heptane $+10 \%$ ethyl acetate to $\mathrm{F} 3$ fraction; $2.5 \mathrm{~mL}$ of heptane $+20 \%$ ethyl acetate for fraction $\mathrm{F} 4$ and $2.0 \mathrm{~mL}$ of ethyl acetate $+2 \mathrm{ml}$ of methanol for the F5 fraction. In this case, only fraction $\mathrm{F} 1$, relative to the $n$-alkanes, and fraction $\mathrm{F} 4$ relative to the sterols, were collected, dried in nitrogen and frozen for further analysis in gas chromatography.
Prior to the chromatographic analysis, F1 extract were resuspended in $100 \mu \mathrm{L}$ of heptane and F4 extract were resuspended in $50 \mu \mathrm{L}$ of heptane plus $50 \mu \mathrm{L}$ of BSTFA and oven-heated at $60^{\circ} \mathrm{C}$ for 30 minutes to derivatize. Samples were injected into a Gas Chromatography equipment, GC7890A, HP Agilent Technologies equipped with FID detector and a $30 \mathrm{~m}$ long HP5 capillary column with $320 \mu \mathrm{m}$ of internal diameter and $0.25 \mu \mathrm{m}$ of film thickness. The injector temperature was $280^{\circ} \mathrm{C} ; 1: 10$ split injection and detector temperature programmed to $320^{\circ} \mathrm{C}$.

To obtain the n-alkanes, a GC method was applied using a pressure of 4.9 psi was applied in the injector, with hydrogen as carrier gas and average velocity of $38.3 \mathrm{~cm} / \mathrm{sec}$ in the column. A ramp of 46.5 minutes was carried out with the furnace initial temperature of $50{ }^{\circ} \mathrm{C}, 10{ }^{\circ} \mathrm{C} \mathrm{min}-1$ to $180{ }^{\circ} \mathrm{C}$ and $5^{\circ} \mathrm{C} \mathrm{min}^{-1}$ to the final temperature of $320^{\circ} \mathrm{C}$.

For sterols, the GC method used a pressure of 5 psi in the injector with hydrogen carrier gas and average speed at the column of $35.3 \mathrm{~cm} \mathrm{sec}^{-1}$. The ramp was 45.5 minutes with initial oven temperature of $100{ }^{\circ} \mathrm{C}$, with $10{ }^{\circ} \mathrm{C} \min ^{-1}$ to $215{ }^{\circ} \mathrm{C}, 5{ }^{\circ} \mathrm{C} \mathrm{min}{ }^{-1}$ to $250{ }^{\circ} \mathrm{C}, 2{ }^{\circ} \mathrm{C} \mathrm{min}-1$ to $280{ }^{\circ} \mathrm{C}$ and $5^{\circ} \mathrm{C} \mathrm{min}^{-1}$ to the final temperature at $320^{\circ} \mathrm{C}$.

Calibration curves were made from $50 \mu \mathrm{g} / \mathrm{L}$ of $5-\alpha$ cholestane standard in solutions concentrations of $10 \%, 25 \%, 50 \%$ and $100 \%$. Prior to extractions n-alkane and sterols recovery standard (squalene and androstanol, respectively) were added. Response factor for n-alkanes and sterols was estimated to be $56 \pm 24 \%$ and $82 \pm 18 \%$, respectively, and was not considered in calculations. Compounds were identified by comparison to commercial standards $\left(\mathrm{C}_{8}-\mathrm{C}_{20}\right.$ short chain n-alkane, $\mathrm{C}_{21}-\mathrm{C}_{40}$ long chain n-alkane, coprostanol, cholesterol, cholestanol, ergosterol, campesterol, stigmaterol, stigmastanol, $\beta$-sitosterol, $\beta$-sitostanol) injected and confirmed using Agilent 7890A gas chromatograph coupled to 5975C MSD quadrupole mass spectrometer. UCM was calculated from base line discounting resolved peaks. The capillary column used was HP-5MS (30 m, $250 \mu \mathrm{m}, 0.25 \mu \mathrm{m}$ ) with temperature programs described below as the same used in GC/FID. Mass detector settings were: ion source temperature $230{ }^{\circ} \mathrm{C}$, quadrupole temperature $150{ }^{\circ} \mathrm{C}$ and auxiliary $280^{\circ} \mathrm{C}$. The detector was autotuned, using routines provided with Agilent Chemstation software. Analysis was carried out with electron energy $70 \mathrm{eV}$ in full scan mode ( $\mathrm{m} / \mathrm{z}$ range 50 to 550 daltons). Samples were analyzed in splitless mode.

The Principal Components Analysis was performed at the program Statistic 7.0 to verify the spatial and seasonal relationships of the variables analyzed providing a more appropriate data view. The Shapiro-Wilk test was performed to test the data normality. When data were not normal, samples were compared using the MannWhitney test. Pearson correlation analysis was performed to verify the relationship between the fluxes and parameters found.

\section{RESULTS AND DISCUSSION}

\section{Environmental parameters}

In 2016, as presented by INMET, ${ }^{39}$ precipitation was higher from January to March and from November to December (Figure 3). April had the lowest rainfall with values lower than those expected for the season (100 mm). December showed higher precipitation, as expected, including rains during collection. The highest temperatures occurred in April, maximum $35^{\circ} \mathrm{C}$, higher than the climatological normal for the season. In December, temperature was $30^{\circ} \mathrm{C}$ on collection days, lower than expected.

The organic matter $(\mathrm{OM})$ at the sediment was very high at sites 2 and 3 in both periods. Values were also higher at site 9 in 


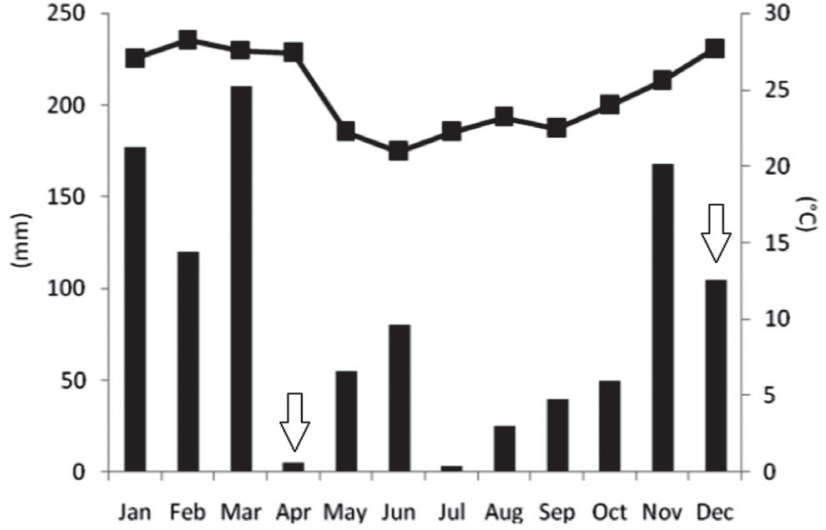

Figure 3. Rainfall data $(\mathrm{mm})$ in bars and average temperature $\left({ }^{\circ} \mathrm{C}\right)$ in lines of the city of Rio de Janeiro in 2016. White arrows indicate the collection periods. Source: INMET ${ }^{39}$

both periods and at site 14 in the wet season. The sediment was predominantly sandy mud. Site 14 was an exception, where sandy sediment predominated (Table 1).

\section{Distribution of n-alkanes}

The lowest total concentration of $n$-alkanes was found at sites $4 \mathrm{~W}\left(1.52 \mu \mathrm{g} \mathrm{g}^{-1}\right)$ and $15 \mathrm{~W}\left(1.02 \mu \mathrm{g} \mathrm{g}{ }^{-1}\right)$, both in the wet season and the highest total concentration was found at site $14 \mathrm{~W}\left(24.27 \mu \mathrm{g} \mathrm{g}^{-1}\right)$ also in the wet season (Table 1). In most sites, the total values were higher in the dry period, except for site 14 . Despite this, $n$-alkanes concentrations were considered statistically different between the seasons $(\mathrm{p}<0,0001)$, according to Mann Whitney test.

Individual $n$-alkanes ranged from $\mathrm{C} 14$ to $\mathrm{C} 38$. C29 was predominant (Table 1) at most sites, followed by $\mathrm{C} 27$ or $\mathrm{C} 31$, showing the importance of the long-chain compounds present in the environment. Unresolved Complex Mixture (UCM) was detected in most collection sites, ranging from $37.74 \mu \mathrm{g} \mathrm{g}^{-1}$ (82.69\% considering resolved and unresolved $n$-alkanes total concentration) at 4D to $224.51 \mu \mathrm{g} \mathrm{g}^{-1}(95.51 \%)$ at site $9 \mathrm{~W}$. The UCM concentration was higher in the wet season, although it was not present at all sites.

Some ratios among the compounds were used to better understand the results. Terrigenous Aquatic Ratio - TAR (Table 2), a ratio of terrestrial compounds $(\mathrm{C} 27, \mathrm{C} 29, \mathrm{C} 31)$ and those of aquatic origin $(\mathrm{C} 15, \mathrm{C} 17, \mathrm{C} 19)^{40}$ suggest whether the organic matter is main aquatic or terrestrial. Values higher than 1.0 indicate terrestrial origin, while lower values indicate aquatic origin. Data are greater than 1.0 at all sites, indicating predominance of terrestrial organic matter sources.

On the other hand, high UCM at most sites indicates petroleum residues. The rate of unresolved to resolved compounds (Unresolved/ Resolved) can be used to indicate the presence of polluted areas. ${ }^{41}$ Values higher than 4,0 suggest areas with petroleum residues..$^{42,43}$ At Rodrigo de Freitas Lagoon almost all Unresolved/Resolved rate presents values higher than 4 , while only site 4 in the dry season shows lower values. This mixture is composed by hydrocarbons derived mainly from oil spills and fossil fuels. The presence of pristane and phytane also indicates contamination by petroleum residues, ${ }^{25,44}$ as they are the main branched $n$-alkanes found in petroleum. Pristane may also be originated from phytol degradation performed by phytoplankton, zooplankton, bacteria..$^{45}$

The Pristane/Phytane ratio (Table 2) confirms these results with values less than 1.0 at most sites. Values close to $1.0-1.5$ indicate hydrocarbons derived from petroleum, while values from 3 to 5 suggest biogenic origin. ${ }^{45}$ The CPI-carbon preference index is used to indicate the origin of $n$-alkanes in marine sediments and the relationship between even and odd $n$-alkanes. ${ }^{46}$ Thus, values between 3 and 6 indicate sources in terrestrial plants, while values close to 1.0 indicate petrogenetic sources. ${ }^{47}$ Therefore, this ratio also ratifies the previous results, with values close to 1.0 in virtually all sites, despite TAR values indicates terrestrial sources. In some cases, lower values $(<0.8)$ have been identified, suggesting the existence of microbial sources. Thus, these analysis indicate that terrestrial or petrogenic sources were shown to be relevant in the organic matter of Rodrigo de Freitas lagoon.

Total concentrations of $n$-alkanes were higher than those found in other studies in Brazil. Carreira et al.,${ }^{48}$ studying Sepetiba Bay that is contaminated by urban and industrial dumps in the state of Rio de Janeiro, found values between 0.26 and $2.65 \mu \mathrm{g} . \mathrm{g}^{-1}$, even though this area presents a more efficient connection with the sea and can reduce the retention time of the organic matter. Maioli et al. ${ }^{21}$ studying the eutrophic Manguaba Lagoon, in Alagoas, northeastern Brazil, found total $n$-alkanes between 0.24 and $1.14 \mu \mathrm{g} \mathrm{g}^{-1}$. It is also a choked lagoon that receives urban sewage, but with a semi-arid climate in the upper basin, presenting a dry summer and a wet winter. A region displaying lower rainfall period presents a lower load of organic matter. However, the present study has found values similar to those of Almeida et al..$^{49}$ in the Reservatório de Funil, at Rio de Janeiro, that was built in 1969 and it is a eutrophic region of flooded Atlantic Forest where concentrations varied between 16.72 and $27.21 \mu \mathrm{g} \mathrm{g}^{-1}$. The presence of Atlantic Forest and the importance of terrestrial organic matter is similar to Rodrigo de Freitas Lagoon.

\section{Distribution of sterols}

The present study identified eleven sterols: coprostanol

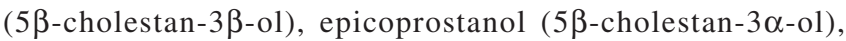
cholesterol (Colest-5-en-3 $\beta$-ol), cholestanone ( $5 \alpha$-colestan-3-one), cholestanol ( $5 \alpha$-cholestan-3 $\beta$-ol), ergosterol $(5,7,22$-Ergostatrien$3 \beta$-ol), campesterol (24-methylcholest-5-en-3 $\beta$-ol), stigmasterol (24-ethylcholest-5,22(E)-dien-3 $\beta$-ol), stigmastanol (24-ethyl-5 $\alpha$ cholestan-3 $\beta$-ol), $\beta$-sitosterol (24-ethylcholest-5-en-3 $\beta$-ol) and $\beta$-sitostanol (24-ethyl-5 $\alpha$-cholestan-3 $\beta$-ol).

Sterols total concentrations varied from $3.5 \mu \mathrm{g} \mathrm{g} \mathrm{g}^{-1}$ at $4 \mathrm{D}$ to $56.01 \mu \mathrm{g} \mathrm{g}^{-1}$ at 9D (Table 1), indicating higher concentrations in the dry period, especially at the site near the Jardim de Alah Channel (Site 9D), where stigmastanol was the main sterol followed by $\beta$-sitosterol and stigmasterol. In the wet season, concentrations were higher at sites 2 and 14, in which $\beta$-sitosterol is the main compound followed by $\beta$-sitostanol and stigmastanol (Table 1 ). Despite this, concentrations were not statistically different between the seasons ( $p>0.05 ; p=0.7572$ ), according to Mann Whitney test.

Sterol compositions indicate great importance of phytosterols ( $\beta$-sitosterol and stigmasterol) and their degradation products ( $\beta$-sitostanol and stigmastanol). The prevalence of them indicates the influence of terrestrial plants in the waters of Rodrigo de Freitas lagoon. These sterols may originate in the course of the Cabeça and Macaco Rivers that flow into the Lagoon, traveling through Atlantic Forest regions until reaching the urban zone, where the vegetation around Rodrigo de Freitas lagoon also contribute. Other degraded products (cholestanone and epicoprostanol) and sewage (coprostanol) were relevant in specific sites such as 9D and 14W, suggesting that river drainage and the connection with the sea are important sources of these compounds.

There is no consensus in the literature on the coprostanol levels indicating sewage contamination. Gonzalez Oreja et al. ${ }^{50}$ have used coprostanol concentration of $>0.5 \mu \mathrm{g} \mathrm{g}^{-1}$ as indicator of contaminated environments. Employing this parameter, sewage contamination was identified at sites 2D $\left(0.55 \mu \mathrm{g} \mathrm{g}^{-1}\right), 9 \mathrm{D}\left(1.8 \mu \mathrm{g} \mathrm{g}^{-1}\right), 2 \mathrm{~W}\left(0.7 \mu \mathrm{g} \mathrm{g}{ }^{-1}\right)$, 9W $\left(0.7 \mu \mathrm{g} \mathrm{g}^{-1}\right), 14 \mathrm{~W}\left(1.9 \mu \mathrm{g} \mathrm{g}^{-1}\right)$ and 17W $\left(0.9 \mu \mathrm{g} \mathrm{g}^{-1}\right)$. 
Table 1. Coordinates, parameters measured, concentrations and main characteristics of $n$-alkanes, sterols and $\mathrm{CH}_{4}$ ebullitive flux found in the Rodrigo de Freitas Lagoon during the dry (D) and wet (W) periods

\begin{tabular}{|c|c|c|c|c|c|c|c|c|c|c|c|c|c|c|c|c|}
\hline \multirow{2}{*}{ SITES } & \multicolumn{2}{|c|}{2} & \multicolumn{2}{|c|}{3} & \multicolumn{2}{|l|}{4} & \multicolumn{2}{|c|}{9} & \multicolumn{2}{|c|}{14} & \multicolumn{2}{|c|}{15} & \multicolumn{2}{|c|}{16} & \multicolumn{2}{|c|}{17} \\
\hline & $\mathrm{D}$ & W & $\mathrm{D}$ & W & D & W & D & W & D & W & $\mathrm{D}$ & W & D & W & $\mathrm{D}$ & $\mathrm{W}$ \\
\hline Lat. (S) & \multicolumn{2}{|c|}{$22^{\circ} 58^{\prime} 01.8^{\prime \prime}$} & \multicolumn{2}{|c|}{$22^{\circ} 58^{\prime} 22.1^{\prime \prime}$} & \multicolumn{2}{|c|}{$22^{\circ} 58^{\prime} 35^{\prime \prime}$} & \multicolumn{2}{|c|}{$22^{\circ} 58^{\prime} 47.4^{\prime \prime}$} & \multicolumn{2}{|c|}{$22^{\circ} 58^{\prime} 07.2^{\prime \prime}$} & \multicolumn{2}{|c|}{$22^{\circ} 58^{\prime} 38.6^{\prime \prime}$} & \multicolumn{2}{|c|}{$22^{\circ} 58^{\prime} 31.3^{\prime \prime}$} & \multicolumn{2}{|c|}{$22^{\circ} 57^{\prime} 49.3^{\prime \prime}$} \\
\hline Long. (W) & \multicolumn{2}{|c|}{$43^{\circ} 12^{\prime} 25.1^{\prime \prime}$} & \multicolumn{2}{|c|}{$43^{\circ} 12^{\prime} 41.3^{\prime \prime}$} & \multicolumn{2}{|c|}{$43^{\circ} 12^{\prime} 18^{\prime \prime}$} & \multicolumn{2}{|c|}{$43^{\circ} 12^{\prime} 49^{\prime \prime}$} & \multicolumn{2}{|c|}{$43^{\circ} 12^{\prime} 58.6^{\prime \prime}$} & \multicolumn{2}{|c|}{$43^{\circ} 12^{\prime} 07^{\prime \prime}$} & \multicolumn{2}{|c|}{$43^{\circ} 12^{\prime} 55.9^{\prime \prime}$} & \multicolumn{2}{|c|}{$43^{\circ} 12^{\prime} 20^{\prime \prime}$} \\
\hline Depth (m) & \multicolumn{2}{|c|}{4.0} & \multicolumn{2}{|c|}{3.95} & 3.6 & & 2.3 & 35 & & 9 & & & & & & 0 \\
\hline $\mathrm{OM}(\%)$ & 16.5 & 20.3 & 16.6 & 17.8 & 9.9 & 4.5 & 13.0 & 16.4 & 2.1 & 16.3 & - & 3.4 & - & 6.7 & - & 8.3 \\
\hline Sand $(\%)$ & 14.9 & 18.9 & 9.9 & 14.4 & 16.9 & 52.3 & 22.0 & 26.3 & 97.6 & 61.1 & - & 21.3 & - & 40.1 & - & 35.0 \\
\hline Silt/Clay (\%) & 85.0 & 81.1 & 90.1 & 85.6 & 83.1 & 47.7 & 78.0 & 73.7 & 2.3 & 38.9 & - & 78.8 & - & 59.9 & - & 65.0 \\
\hline & & & & & & & & -alkanes & $\left(\mu \mathrm{g} \mathrm{g}^{-1}\right)$ & & & & & & & \\
\hline Max & $\mathrm{C} 29$ & $\mathrm{C} 29$ & $\mathrm{C} 29$ & $\mathrm{C} 16$ & $\mathrm{C} 16 / \mathrm{C} 29$ & $\mathrm{C} 16$ & $\mathrm{C} 29$ & $\mathrm{C} 29$ & $\mathrm{C} 16$ & $\mathrm{C} 29$ & - & C16 & - & $\mathrm{C} 29$ & - & $\mathrm{C} 29$ \\
\hline SC & 1.76 & 1.46 & 1.76 & 0.91 & 2.47 & 0.59 & 2.95 & 1.75 & 1.43 & 2.82 & - & 0.96 & - & 1.23 & - & 1.90 \\
\hline $\mathrm{LC}$ & 10.65 & 4.39 & 7.59 & 1.3 & 4.1 & 0.8 & 12.0 & 7.61 & 1.88 & 17.96 & - & 0.74 & - & 2.83 & - & 6.14 \\
\hline $\mathrm{UCM}$ & 217.33 & 110.91 & 122.17 & nd & 37.74 & nd & 175.95 & 224.51 & nd & 215.50 & - & nd & - & nd & - & 162.15 \\
\hline Total & 14.0 & 6.65 & 10.38 & 2.40 & 7.9 & 1.52 & 16.75 & 10.53 & 3.73 & 24.27 & - & 1.02 & - & 4.53 & - & 9.56 \\
\hline & & & & & & & & Sterols ( & $\left.\operatorname{lg~g~}^{-1}\right)$ & & & & & & & \\
\hline cop & 0.55 & 0.72 & 0.02 & 0.02 & 0.04 & 0.10 & 1.83 & 0.77 & 0.45 & 1.94 & - & 0.04 & - & 0.06 & - & 0.98 \\
\hline epi & 0.02 & 0.02 & 0.02 & 0.12 & 0.04 & 0.12 & 3.67 & 1.04 & 1.24 & 6.32 & - & 0.03 & - & 0.02 & - & 1.40 \\
\hline col & 2.23 & 3.10 & 0.12 & 0.05 & 0.16 & 0.59 & 4.79 & 2.67 & 0.56 & 2.07 & - & 0.16 & - & 0.50 & - & 3.01 \\
\hline c-ona & 1.03 & 0.81 & 0.04 & 0.06 & 0.47 & 0.07 & 0.18 & 0.98 & 0.26 & 0.61 & - & 0.02 & - & 0.06 & - & 1.02 \\
\hline c-nol & 1.00 & 1.64 & 0.12 & 0.09 & 0.07 & 0.18 & 2.68 & 1.98 & 0.42 & 1.79 & - & 0.53 & - & 0.08 & - & 1.43 \\
\hline erg & 1.71 & 1.56 & 0.30 & 0.14 & 0.12 & 0.09 & 0.21 & 0.50 & 0.02 & 0.02 & - & 0.02 & - & 0.05 & - & 0.81 \\
\hline camp & 2.91 & 3.41 & 0.38 & 0.15 & 0.14 & 0.46 & 3.79 & 1.62 & 0.13 & 0.93 & - & 0.07 & - & 0.19 & - & 1.20 \\
\hline stig & 2.82 & 3.53 & 0.29 & 0.13 & 0.29 & 0.52 & 7.96 & 1.26 & 0.19 & 2.64 & - & 0.35 & - & 0.21 & - & 0.63 \\
\hline stig-nol & 0.52 & 1.44 & 0.25 & 0.90 & 1.26 & 0.78 & 16.42 & 3.47 & 0.51 & 4.52 & - & 1.47 & - & 1.97 & - & 2.59 \\
\hline sit & 7.82 & 6.72 & 2.51 & 1.09 & 0.51 & 1.71 & 11.40 & 6.91 & 1.24 & 6.93 & - & 1.55 & - & 0.82 & - & 4.98 \\
\hline sit-nol & 10.31 & 7.36 & 4.00 & 2.76 & 0.40 & 4.10 & 3.07 & 4.10 & 2.64 & 3.50 & - & 0.55 & - & 1.49 & - & 3.15 \\
\hline Total & 30.9 & 30.2 & 8.0 & 5.5 & 3.5 & 8.7 & 56.0 & 25.3 & 7.6 & 31.2 & - & 4.7 & - & 5.4 & - & 21.2 \\
\hline & & & & & & & ebull & itve flux & $\mathrm{mg} \cdot \mathrm{m}^{-2}$ & & & & & & & \\
\hline
\end{tabular}

*Water depth = average of the two collections; OM = organic matter; Sand = sand percentage; Silt/Clay = Silt + Clay percentage; UCM = Unresolved Complex Mixture; Max = Carbon number with maximum concentrations; $\mathrm{SC}=$ Short chain $(\leq \mathrm{C} 20) ; \mathrm{LC}=$ Long chain $(>\mathrm{C} 20) ;-$ indicates no collection; nd = not detectable; $\mathrm{cop}=$ coprostanol; epi = epicoprostanol; $\mathrm{col}=$ cholesterol; $\mathrm{c}$-ona $=$ cholestanone; $\mathrm{c}$-nol = cholestanol; erg = ergosterol; camp = campesterol; stig = stigmaterol; stig-nol = stigmastanol; sit $=\beta$-sitosterol; sit-nol $=\beta$-sitostanol

Table 2. Ratios of n-alkanes (TAR, Pr/Phy and CPI) and sterols (epi / cop)

\begin{tabular}{ccccc}
\hline Site & TAR & Pr/Phy & CPI & epi/cop \\
\hline 2D & 9.83 & 1.39 & 1.44 & nd \\
3D & 11.15 & 1.35 & 1.28 & nd \\
4D & 3.46 & 0.59 & 0.92 & 0.89 \\
9D & 6.25 & 0.53 & 1.54 & 2.00 \\
14D & 2.32 & 0.95 & 0.78 & 2.76 \\
2W & 4.33 & 0.77 & 1.58 & nd \\
3W & 2.17 & 1.04 & 0.25 & nd \\
4W & 3.62 & 0.72 & 0.64 & 1.17 \\
9W & 6.41 & 0.77 & 1.55 & 1.35 \\
$14 \mathrm{~W}$ & 6.23 & 0.47 & 1.59 & 3.25 \\
$15 \mathrm{~W}$ & 1.34 & 0.93 & 0.55 & 0.76 \\
$16 \mathrm{~W}$ & 3.70 & 3.16 & 1.12 & 0.35 \\
$17 \mathrm{~W}$ & 4.10 & 0.63 & 0.99 & 1.43 \\
\hline
\end{tabular}

$\mathrm{TAR}=\mathrm{C} 27+\mathrm{C} 29+\mathrm{C} 31 / \mathrm{C} 15+\mathrm{C} 17+\mathrm{C} 19 ; \mathrm{Pr} / \mathrm{Phy}=$ Pristane $/$ Phytane $\mathrm{CPI}=$ even $\mathrm{n}$-alkanes $/$ odd $\mathrm{n}$-alkanes; epi/cop = epicoprostanol/coprostanol
Grimalt et al. ${ }^{20}$ established the use of coprostanol to cholestanol ratio $(5 \beta / 5 \beta+5 \alpha)$ to evaluate the influence of domestic effluents on continental aquatic ecosystems. Santos et al. ${ }^{26}$ suggest that values above 0.5 indicate highly sewage contaminated tropical environments, while values lower than 0.3 indicate no contamination (Figure 4). Considering this parameter, site 14 was highly contaminated by sewage (0.52), as well as there was fecal influence at sites $2(0.35$ and 0.31$)$ and $4(0.37$ and 0.36$)$ in the two seasons, and at sites 9D (0.41), 3W (0.37), 16W (0.41) and 17W (0.41). Sewage discharge in Rodrigo de Freitas lagoon is also reported in a study indicating its contamination by several heavy metals such as $\mathrm{Hg}, \mathrm{Pb}, \mathrm{Cu}$ and $\mathrm{Zn}$ in its most recent sedimentary layers. ${ }^{51}$ Van Weerelt, Signorini, and Enrich-Prast ${ }^{32}$ also indicated the existence of fecal origin organic matter in the water of Rodrigo de Freitas Lagoon through total coliforms analysis.

Epicoprostanol to coprostanol ratio (Table 2) discriminates the presence of treated and untreated sewage, ${ }^{52}$ in which values lower than 0.2 indicate untreated sewage, whereas levels higher than 0.8 suggest treated sewage. Thus, the results indicated sewage degradation at site 14 (2.76 and 3.25), while it was considered not degraded or degraded long ago at sites 15 and 16 ( 0.76 and 0.35 , respectively), since at these points dump of the dredged sediment occurred at site 17 . 


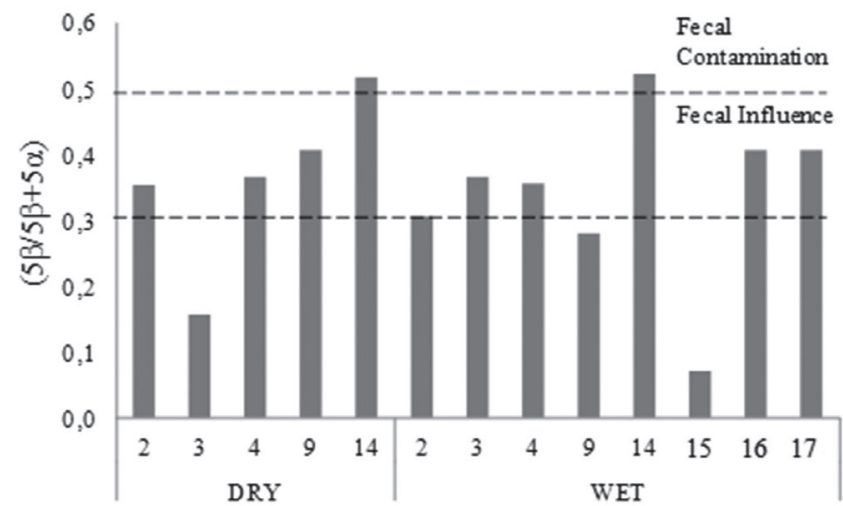

Figure 4. Ratio between coprostanol and cholestanol $(5 \beta / 5 \beta+5 \alpha)$ in the Rodrigo de Freitas Lagoon per site during the dry and wet seasons

A decade before of this study, Stefens et al ${ }^{53}$ found higher fecal sterols concentrations in this lagoon, mainly in the site 15 , were it has been disposed the dragged sediments. Comparing our values with other studies (Table 3), it was observed that coprostanol concentrations and the ratio $(5 \beta / 5 \beta+5 \alpha)$ were higher than in some studies carried out in the North, Southeast and South regions of Brazil, such as the MundaúManguaba Lagoon, in Alagoas, Sepetiba Bay in Rio de Janeiro, Patos Lagoon in Rio Grande do Sul and in Concepcion Bay in Chile. ${ }^{48,54-56}$ Similar comparison was also found in $n$-alkanes quantification at Mundaú-Manguaba and Sepetiba Bay. Patos Lagoon in Rio Grande do Sul is the largest coastal lagoon that suffers with great anthropic pressure from urban, rural and industrial activities. This largest area may permit a better circulation in those waters. Concepcion Bay in Chile is a semi-enclosed bay that receives domestic and industrial waste discharges and the better connection with the sea enables the circulation of the organic matter. However, concentrations were lower than those found in the State of Rio de Janeiro as in Araruama Lagoon, Guanabara Bay, Santos Bay and in another countries like Dorchester Bay and Ria de Aveiro Lagoon. 22,57,58,60,68 The Araruama Lagoon, a hypersaline lagoon that underwent a disordered occupation process in its surroundings, receives a large input of organic matter from domestic sewage; the Guanabara Bay, an estuary also located in the urban area of Rio de Janeiro that receives sewage from several rivers flowing in its waters; the Santos Bay in São Paulo and other regions in the world, such as the Dorchester Bay in the USA and Ria de Aveiro lagoon in Portugal, environments under sewage discharge due to urbanization and terrestrial runoff process. The more intense urbanization process and the large amounts of domestic and industrial effluents may be the reason for the higher coprostanol values in those regions.
Although no significant differences have been found, higher concentrations of $n$-alkanes and sterols in the dry period might be due to the early collection in the season, still under the influence of all organic matter accumulation in the sediment during the wet season. As described by Marotta, ${ }^{62}$ rains are responsible for large organic accumulations of nutrients and indicate the need for a more efficient exchange between the lagoon and the sea as pointed out by Rosman. ${ }^{33}$

\section{Ebullitive Flux}

The ebullitive flux of $\mathrm{CH}_{4}$ ranged from $0.11 \mathrm{mg} \mathrm{CH}_{4} \mathrm{~m}^{-2} \mathrm{~d}^{-1}$ at site $2 \mathrm{~W}$ to $888.401 \mathrm{mg} \mathrm{CH}_{4} \mathrm{~m}^{-2} \mathrm{~d}^{-1}$ at site $14 \mathrm{D}$ (Table 1). The mean flux rate was $199.01 \pm 386.8 \mathrm{mg} \mathrm{CH}_{4} \mathrm{~m}^{-2} \mathrm{~d}^{-1}$ in the dry period and $9.3 \pm 17.3 \mathrm{mg} \mathrm{CH}_{4} \mathrm{~m}^{-2} \mathrm{~d}^{-1}$ in the wet season .

The ebullitive flux is the main source of methane into the atmosphere ${ }^{63,64}$ and can reach more than $98 \%$ of the gas flux in shallow lagoons. ${ }^{65,66}$ Methane concentration inside bubbles can reach the surface and represents more than $90 \%$ of the gas present in the sediment, since it can pass through the oxidation processes in sediment upper layers without being affected. ${ }^{65}$

\section{Comparison between $\mathrm{CH}_{4}$ ebullitive flux and organic matter}

Pearson's correlation (Table 4) showed that water column depth negatively correlated with methane ebullitive flux, coprostanol, epicoprostanol, pristane and phytane. In granulometry analysis, sand percentage showed positive correlation with methane ebullitive flux, epicoprostanol, pristane and phytane, while correlations were negative with mud.

Sediment granulometry is an important factor for $\mathrm{CH}_{4}$ ebullitive flux. ${ }^{67}$ Thicker sand sediments favor the capillary gas migration, whereas in thinner sediments, such as mud, gases migrate through fractures with less percolation. In Santos Bay, Brazil, Martins et al. ${ }^{68}$ also found higher sterols concentration in sites with higher concentration of silt and clay.

In the present study, site 14 is the only one with sandy sediment, which can explain the higher gas emission at this site, since it is not retained in the sediment. Positive correlation between $\mathrm{CH}_{4}$ flux with sand content and the negative correlation with mud corroborate these results.

The negative correlation between $\mathrm{CH}_{4}$ ebullitive flux and water column depth is direct related to pressure. Thus, hydrostatic pressure is reduced when in a lower depth, reducing gas solubility and increasing its emission. ${ }^{69}$ This relation was also found in other natural lakes and reservoirs. ${ }^{69,70}$ Sterols and $n$-alkanes concentrations

Table 3. Comparison of coprostanol data with other studies

\begin{tabular}{lccc}
\hline & Coprostanol & RCopro & Reference \\
\hline Dorchester Bay (EUA) & $0.26-12.0$ & - & 60 \\
Concepcion Bay (Chile) & $0.68 \pm 0.46$ & $0.1-0.5$ & 61 \\
Ria de Aveiro Lagoon, (Portugal) & $0.4-11.5$ & - & 22 \\
Guanabara Bay (RJ-BR) & $0.33-40.0$ & $0.13-0.84$ & 58 \\
Santos Bay (SP-BR) & nd-8.51 & $0.43-0.77$ & 68 \\
Sepetiba Bay (RJ-BR) & $0.01-0.42$ & $0.08-0.48$ & 48 \\
Araruama lagoon (RJ-BR) & nd-287.0 & 57 \\
Patos lagoon (RS-BR) & nd-0.92 & -8.85 & 59 \\
Mundaú-Manguaba lagoon (AL-BR) & $0.15-5.65$ & nd- 0.39 & 54 \\
Rodrigo de Freitas lagoon (RJ-BR) & nd- -1.9 & $0.07-0.52$ & This study \\
\hline
\end{tabular}

*Coprostanol in $\mu \mathrm{g} . \mathrm{g}^{-1}$. 
Table 4. Pearson correlation between methane flux and the parameters found in the Rodrigo de Freitas Lagoon. The underlined values showed $\mathrm{p}<0.05$

\begin{tabular}{|c|c|c|c|c|c|c|c|}
\hline & Depth & $\mathrm{OM}$ & Sand & Silt/Clay & $\mathrm{CH}_{4} \mathrm{e}$ & Tst & Talk \\
\hline Depth & 1.00 & & & & & & \\
\hline $\mathrm{OM}$ & 0.36 & 1.00 & & & & & \\
\hline Sand & $\underline{-0.78}$ & $\underline{-0.71}$ & 1.00 & & & & \\
\hline Silt/Clay & $\underline{0.78}$ & $\underline{0.71}$ & $\underline{-1.0}$ & 1.00 & & & \\
\hline $\mathrm{CH}_{4} \mathrm{e}$ & -0.62 & $\underline{-0.65}$ & $\underline{0.8}$ & $\underline{-0.8}$ & 1.00 & & \\
\hline Tst & -0.24 & 0.35 & -0.1 & 0.1 & -0.19 & 1.00 & \\
\hline Talk & -0.43 & 0.38 & -0.1 & 0.1 & -0.23 & $\underline{0.69}$ & 1.00 \\
\hline
\end{tabular}

show the same correlation, since large amounts of organic matter is related with a silted region.

A negative association between sterols and $n$-alkanes concentration with methane ebullitive flux, or between organic matter concentration with methane flux was found. As previously discussed, the differences in granulometry affect organic matter concentration at the sediment and affect this correlation. At wet season, it was raining in the collection week and a recent organic matter was discharging in the lagoon. This explain the higher values of organic matter, sterols and alkanes in this season, mainly in site 14 and also affects the correlation. In this case the organic matter is recent and has not yet been degraded, thus the gas emission is lower.

Harrison et $a l .{ }^{71}$ and Del Sontro et al..$^{72}$ consider that eutophication is an important factor for ebullitive activity. Many works, such as Marota et al. ${ }^{62}$ Van Weerelt, Signorini, and Enrich-Prast ${ }^{32}$ and Soares et al. ${ }^{73}$ consider Rodrigo de Freitas Lagoon as eutrophic. The highest gas emissions to the atmosphere occurred at site 14, mainly in the dry season,with the highest alkanes and sterols concentrations in the wet season, which is also the only region considered highly sewage contaminated. The intense entry of organic matter through the discharge of the Cabeça and Macaco Rivers in this region is an important source for ebullitive flux increase, besides other factors such as low depth and sandy sediment, which generate hotspots for gas emission. The higher organic matter input from sewage sludge and eutrophication contributes with more material to be degraded by decomposing organisms and favors methanogenesis. ${ }^{74-77}$ The anoxic decomposition process considers the organic compounds conversion into $\mathrm{CH}_{4}$, and methanogenesis is one step of this process. ${ }^{78}$ Rapid inflow and consequent accumulation of materials also help increasing the release of these gases from the sediment. ${ }^{79,75}$ Gas fluxes into the atmosphere, however, do not directly quantify $\mathrm{CH}_{4}$ produced during organic matter degradation, since part of the produced $\mathrm{CH}_{4}$ can be oxidized in the water column..$^{80,81}$

The principal components analysis pointed Factor 1 explaining $50.31 \%$ of data variability and Factor 2 explaining $17.44 \%$. Thus, $67.75 \%$ of data variation was determined by these two forcers (Figure 5). Three groups were formed by these analysis: the first one with sites $14 \mathrm{D}$ and $14 \mathrm{~W}$, separated from the others and with some distance between each other. Methane Ebullitive Flux and concentrations of pristane, phytane, coprostanol and epicoprostanol were the main parameters used to determine this group. The second one comprised most of the wet season sites (15W, 4W, 3W, 16W), as well as 3D and 4D. It was formed mainly by Pristane/Phytane concentration, depth and mud. A third group was formed by some dry and wet season sites (9D, 9W, 2D, 2W, and 17W) and is similar in the other alkanes and sterols.

This analysis corroborates the differences at site 14, which is distant to the others. The second and third groups are formed considering the lagoon hydrodynamics. Sites 3, 4, 15 e 16 are placed near the Jardim de Alah Channel, in a region that receives more
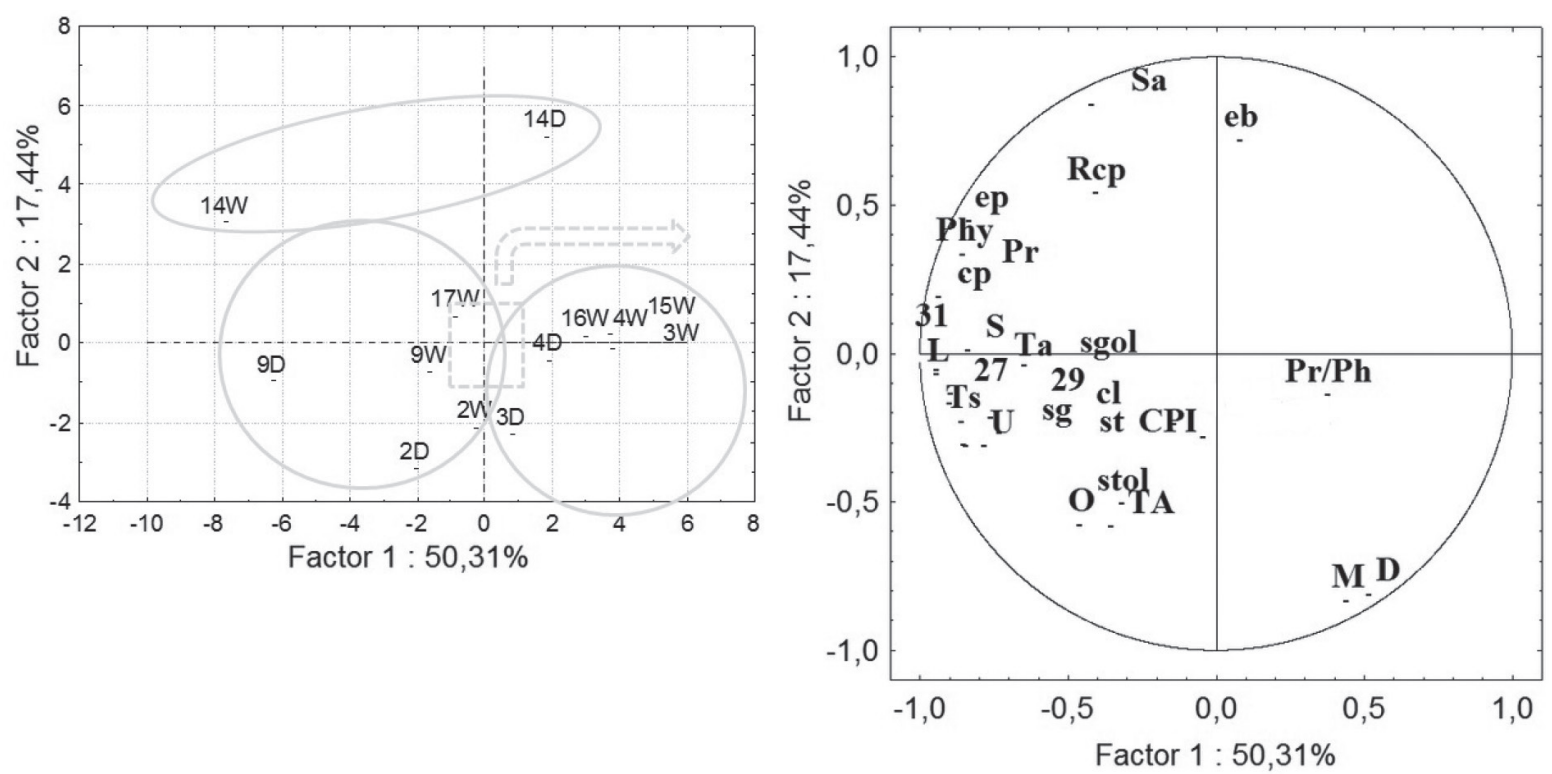

Figure 5. Principal Component Analysis performed among sampling points at the Rodrigo de Freitas Lagoon. Sa = sand; eb=methane ebullitive flux; Pr/ $P h=$ Pristane/Phytane ratio; $P r=$ Pristane Phy = Phytane; $27=C 27 ; 29=C 29 ; 31=C 31 ; U=U C M ; L=$ long chain; $S=$ small chain $;$ Ta = Total $n$-alkanes; $C P I=$ Carbon Preference Index; TA = Terrigenous Aquatic rate; $D=$ depth; $M=$ mud; stol = sitostanol; st = sitosterol; sg = stigmasterol; sgol = stigmastanol; $c l=$ cholesterol $; c p=$ coprostanol $;$ ep $=$ epicoprostanol $; \mathrm{R} p=(5 \beta / 5 \beta+5 \alpha)$ rate $;$ Ts $=$ Total sterol 
influence from the ocean waters, while sites 2 and 17 are located in the internal region and with less influence of it. Site 9 is an exception, because although it is situated in the discharge of the Jardim de Alah Channel, this channel is also a source of domestic effluents, being similar to site 14 , presenting sewage discharge.

\section{CONCLUSIONS}

The Rodrigo de Freitas Lagoon is a source of atmospheric methane $\left(83.5\right.$ ton $\left.\mathrm{CH}_{4} / \mathrm{yr}\right)$, presenting sewage contaminated regions and petroleum derivatives influence that contribute to the increased emissions.

This study helps to better understand the input and output dynamics of nutrients and organic matter in this environment, since these factors affect all the surrounded biota and population. Despite the works and improvements in the Rodrigo de Freitas Lagoon basin, there is still the urban perimeter washing that carries oil derivatives to its waters, irregular sewage discharge in several sites, as well as the need for more efficient water exchanges between this lagoon and the sea.

\section{ACKNOWLEDGEMENTS}

The authors are grateful to Prof. Dsc. Marcos Nicolas Gallo from COOPE/UFRJ for helping in sediment composition analysis, to Prof. Dsc. Sandra Azevedo for the material, and Municipal Environment Secretariat/City Hall of the city of Rio de Janeiro (SMAC) for provided some data. This study was financed in part by the Coordenação de Aperfeiçoamento de Pessoal de Nível Superior - Brasil (CAPES) - Finance Code 001. Marcelo Correa Bernardes are grateful to $\mathrm{CNPq}$ for the productivity fellowship. Priscila P. A. Murolo (INSIGHT Traduções) translated the text.

\section{REFERENCES}

1. https://www.ipcc.ch/report/ar5/wg1/, acessado em junho de 2019.

2. https://library.wmo.int/opac/doc_num.php?explnum_id=4453, acessado em junho de 2019.

3. Saunois, M.; Bousquet, P.; Poulter, B.; Peregon, A.; Ciais, P.; Canadell, J. G.; Dlugokencky, E. J.; Etiope, G.; Bastviken, D.; Houweling, S.; Janssens-Maenhout, G.; Tubiello, F. N.; Castaldi, S.; Jackson, R. B.; Alexe, M.; Arora, V. K.; Beerling, D. J.; Bergamaschi, P.; Blake, D. R.; Brailsford, G.; Brovkin, V.; Bruhwiler, L.; Crevoisier, C.; Crill, P.; Covey, K.; Curry, C.; Frankenberg, C.; Gedney, N.; Höglund-Isaksson, L.; Ishizawa, M.; Ito, A.; Joos, F.; Kim, H.-S.; Kleinen, T.; Krummel, P.; Lamarque, J.-F.; Langenfelds, R.; Locatelli, R.; Machida, T.; Maksyutov, S.; McDonald, K. C.; Marshall, J.; Melton, J. R.; Morino, I.; Naik, V.; O’Doherty, S.; Parmentier, F.-J. W.; Patra, P. K.; Peng, C.; Peng, S.; Peters, G. P.; Pison, I.; Prigent, C.; Prinn, R.; Ramonet, M.; Riley, W. J.; Saito, M.; Santini, M.; Schroeder, R.; Simpson, I. J.; Spahni, R.; Steele, P.; Takizawa, A.; Thornton, B. F.; Tian, H.; Tohjima, Y.; Viovy, N.; Voulgarakis, A.; van Weele, M.; van der Werf, G. R.; Weiss, R.; Wiedinmyer, C.; Wilton, D. J.; Wiltshire, A.; Worthy, D.; Wunch, D.; Xu, X.; Yoshida, Y.; Zhang, B.; Zhang, Z.; Zhu, Q.; Earth. Syst. Sci. 2016, 8, 697.

4. Davidson, T. A.; Audet, J.; Jeppesen, E.; Landkildehus, F.; Lauridsen, T,L,; Søndergaard, M.; Syväranta, J.; Nat. Clim. Change 2018, 8, 56.

5. Kjerfve, B.; Coastal lagoons, Elsevier Science Publishers B.V., 1994

6. Sobek, S.; Algesten, G.; Bergstrom, A.; Jansson, M.; Tranvik, L.; Global Change Biology 2003, 9, 630.

7. Tranvik, L. J.; Downing, J. A.; Cotner, J. B.; Loiselle, S. A.; Striegl, R. G.; Ballatore, T. J.; Dillon, P.; Finlay, K.; Fortino, K.; Knoll, L. B.; Kortelainen, P. L.; Kutser, T.; Larsen, S.; Laurion, I.; Leech, D. M.;
McCallister, S. L.; McKnight, D. M.; Melack, J. M.; Overholt, E.; Porter, J. A.; Prairie, Y.; Renwick, W. H.; Roland, F.; Sherman, B. S.; Schindler, D. W.; Sobek, S.; Tremblay, A.; Vanni, M. J.; Verschoor, A. M.; von Wachenfeldt, E.; Weyhenmeyer, G. A.; Limnol. Oceanogr. 2009, 54, 2298.

8. Bastviken, D.; Cole, J. J.; Pace, M. L.; Van de Bogert, M. C.; J. Geophys. Res.: Biogeosci. 2008, 113, G02024.

9. Cole, J. J.; Prairie, Y. T.; Caraco, N. F.; McDowell, W. H.; Tranvik, L. J.; Striegl, R. G.; Duarte, M.; Kortelainen, P.; Downing, J. A.; Middelburg, J. J.; Melack, J. ; Ecosystems 2007, 10, 171.

10. Utsumi, M.; Nojiri, Y.; Nakamura, T.; Nozawa, T.; Otsuki, A.; Limnol. Oceanogr. 1998. 43, 10.

11. Bastviken, D.; Cole, J. J.; Pace, M.; Tranvik, L.; Global Biogeochem. Cycles 2004, 18, 1.

12. Grinham, A.; Dunbabin, M.; Albert, S.; Sci. Total Environ. 2018, 621, 1199.

13. Huttunen J. T.; Alm, J.; Liikanen, A.; Juutinen, S.; Larmola, T.; Hammar, T.; Silvola, J.; Martikainen, P. J. Chemosphere. 2003, 52, 609.

14. Wakeham, S. G.; Hedges, J. I.; Lee, C.; Peterson, M. L.; Hernes, P. J.; Deep-Sea Res. 1997, 44, 2131.

15. Atlas, R.; Microbiol. Rev. 1981, 45, 180.

16. Ishiwatari, R.; Uzaki, M.; Geochim. Cosmochim. Acta. 1987, 51, 321.

17. Meyers, P. A.; Org. Geochem. 1997, 27, 213.

18. Volkman, J. K.; Holdsworth, D. G.; Neill, G. P.; Bavor Jr., H. J.; Sci. Total Environ. 1992, 112, 203.

19. Nguyen, D. K.; Bruchet, A.; Arpino, P.; Environ, Sci. Technol. 1995, 29, 1686

20. Grimalt, J. O.; Ferninder, P.; Bayona, J. M.; Albaigis, J.; Environ. Sci. Technol. 1990, 24, 357.

21. Maioli, O. L. G.; Oliveira. C. R.; Dal Sasso, M. A.; Madureira, L. A. S.; Azevedo, D. A.; Aquino Neto, F. R.; Estuarine, Coastal Shelf Sci. 2012, $114,140$.

22. Rada, J. P. A.; Duarte, A. C.; Pato, P.; Cachada, A.; Carreira, R.; Mar. Pollut. Bull. 2016, 103, 319.

23. Carreira, R. S.; Cordeiro, L. G. M. S.; Bernardes, M. C.; Hatje, V.; Estuarine, Coastal Shelf Sci. 2016, 168, 1.

24. Volkman, J. K.; Org. Geochem. 1986, 9, 83.

25. Saliot, A.; Laureillard, J.; Scribeand, P.; Sicre M. A.; Mar. Chem. 1991, 36, 233.

26. Santos, E. S.; Carreira, R. S.; Knoppers, B. A.; Braz. J. Oceanogr. 2008, $56,97$.

27. http://www.prefeitura.rio/documents/91265/2972533/9++RIOAGUAS+-+Plano+de+Conting\%C3\%AAncia+e+Monitoramen to+-+2013, acessado em junho de 2019.

28. https://censo2010.ibge.gov.br, acessado em junho de 2019.

29. Oliveira, R. R.; Dissertação de Mestrado, Universidade do Estado do Rio de Janeiro, Brasil, 2013.

30. Kjerfve, B.; Magill, K. E.; Mar. Geol. 1989, 88, 187

31. Araújo, C. L.; Monografia, Universidade Estadual do Rio de Janeiro, Brasil, 2008.

32. Van Weerelt, M. D. M.; Signorini, C.; Enrich-Prast, A.; Oecologia Australis 2012, 16, 566.

33. Rosman, P. C. C.; Oecologia Australis 2012, 16, 651.

34 Wentworth, C. K.; J. Geol. 1922, 30, 377.

35. Associação Brasileira de Normas Técnicas (ABNT). NBR 10664. Rio de Janeiro. 1989.

36. Brasil, Ministério de Minas e Energia, Diretrizes para análises quantitativas de emissões líquidas de gases de efeito estufa em reservatório, Rio de Janeiro: Programa de Medição e Análise de dados. 2012.

37. https://unesdoc.unesco.org/ark:/48223/pf0000181713, acessado em junho de 2019.

38. Wakeham, S. G.; Canuel, E. A.; J. Mar. Res. 1988, 46,183. 
39. INMET 2016.

40. Bourbonniere, R. A.; Telfor, S. L.; Ziolkowski, L. A.; Lee, J.; Evans, M. S.; Meyers, P. A. Em Biogeochemical Marker Profiles in Cores of Dated Sediments from Large North American Lakes; Eganhouse, R. P., ed.; American Chemical Society: Washington, D. C., 1997.

41. Readman, J. W.; Fillmann, G.; Tolosa, I.; Bartocci, J.; Villeneuve, J. P.; Catinni, C.; Mee, L. D.; Mar. Pollut. Bull. 2002, 44, 48.

42. Mazurek, M. A.; Simoneit, B. R. T.; Identification and Analysis of Organic Pollutants in Air; Keith, L. H., ed.; Ann Arbor Science/ Butterworth: Boston, 1984, pp. 353-370.

43. Lipiatou, E.; Saliot, A.; Mar. Pollut. Bull. 1991, 22, 297.

44. Aloulou, F.; Kallel, M.; Dammak, M.; Elleuch, B.; Saliot, A.; Environ. Earth Sci. 2010, 61, 1.

45. Steinhauer, M. S.; Boehm, P. D.; Mar. Environ. Res. 1992, 33, 223.

46. Bray, E. E.; Evans, E. D. Geochim. Cosmochim. Acta. 1961, $22,2$.

47. Rushdi, A. I.; DouAbul, A. A.; Mohammed, S. S.; Simonneit, B. R. T.; Environ. Geol. 2006, 50, 857.

48. Carreira, R. S.; Ribeiro, P. V.; Silva, C. E. M.; Quim. Nova 2009, 32, 1805.

49. Almeida, P. F. C. F.; Barbosa, L. R.; Cunha, T. S.; Bernardes, M. C.; Vidal, L. O.; Roland, F.; Geochim. Bras. 2014, 28, 201.

50. Gonzalez-Oreja, J. A.; Sainz-Salinas, J. I.; Mar. Pollut. Bull. 1998, 36, 868.

51. Loureiro, D.D.; Dissertação de Mestrado, Universidade Federal Fluminense, Brasil, 2016.

52. McCalley, D.V.; Cooke, M.; Nickless, G.; Water Res. 1981, 15, 1019.

53. Steffens, J. L.; Santos, J. H. Z.; Mendonça Filho, J. G.; Silva, C. G. A.; Peralba, C. R.; J. Environ. Sci. Health A 2007, 42, 1553.

54. Araújo, M. P.; Costa, T. L. F.; Carreira, R. S.; Quim. Nova 2011, 34, 64.

55. Martins, C. C.; Fillmann, G.; Montone, R. C.; J. Braz. Chem. Soc. 2007, 18,106

56. Seguel, C. G.; Mudge, S.; Salgado, C.; Toledo, M.; Water Res. 2001, 35, 4166.

57. Guerra L.V.; Dissertação de Mestrado, Universidade Federal Fluminense, Brasil, 2008.

58. Carreira, R. S.; Wagener, A. L. R.; Readman, J. W.; Estuarine, Coastal Shelf Sci. 2004, 60, 587.

59. Martins, C. C.; Fillmann, G.; Montone, R. C.; J. Braz. Chem. Soc. 2007, 18,106

60. Eganhouse, R. P.; Sherblom, P. M.; Mar. Environ. Res. 2001, 51, 51.

61. Seguel, C. G.; Mudge, S.; Salgado, C.; Toledo, M.; Water Res. 2001, 35, 4166.
62. Marotta, H.; Ricci.; R. M. P.; Sampaio, P. L.; Melo, P. P.; Enrich-Prast, A.; Oecologia Australis 2012, 16, 391.

63. Abril, G.; Guérin, F.; Richard, S.; Delmas, R.; Galy-Lacaux, C.; Gosse, P.; Tremblay, A.; Varfalvy, L.; Santos, M. A.; Matvienko, B.; Global Biogeochem. Cycles 2005, 19, GB4007.

64. Casper, P.; Maberly, S. C.; Hall, G. H.; Finlay, B.; Biogeochemistry. 2000, 49,1 .

65. Katsman, R.; Ostrovsky, I.; Makovsky, Y.; Earth Planet. Sci. Lett. 2013, 377-378, 336

66. Keller, M.; Stallard, R.F.; J. Geophys. Res. 1994, 99, 8307.

67. Jain, A.K.; Juanes, R.; J. Geophys. Res. 2011, 114, B08101.

68. Martins, C. C.; Gomes, F. B. A.; Ferreira, J. A.; Montone, R. C.; Quim. Nova 2008, 31, 1008.

69. Mello, N. A. S. T.; Brighenti, L. S.; Barbosa, F. A. R.; Staehr, P. A.; Bezerra Neto, J. F.; Lake Reservoir Manage. 2018, 34, 105.

70. Souza, R. S.; Tese de doutorado, Universidade Federal do Rio Grande do Sul, Brasil, 2014.

71. Harrison, J. A.; Deemer, B. R.; Birchfield, M. K.; O’Malley, M. T.; Environ. Sci. Technol. 2017, 51, 1267.

72. DelSontro, T.; Boutet, L.; St-Pierre, A.; del Giorgio, P. A.; Prairie, Y. T.; Limnol. Oceanogr. 2016, 00, 1.

73. Soares, M. F.; Domingos, P.; Soares, F. F. P.; Telles, L. F.; Oecologia Australis 2012, 16, 581.

74. Blaha, D.; Bartlett, K.; Czepiel, P.; Harriss, R.; Crill, P.; Atmos. Environ. 1999, 33, 243.

75. Egger, M.; Lenstral, W.; Jongl, D.; Meysman, R.; Sapart, C. J.; Van der Veen, C.; Röckmann, T.; Gonzalez, S.; Slomp, C. P.; PloS One 2016, 11, e0161609.

76. Singh, S. N.; Kulshreshtha, K.; Agnihotri, S.; Chemosphere: Global Change Sci. 2000, 2, 39.

77. Souza, L. M. B.; Dissertação de Mestrado, Universidade Estadual do Norte Fluminense, Brasil, 2008.

78. Madigan, M. T.; Martinko, J. M.; Bender, K. S.; Buckley, D. H.; Stahl, D. A. Em Microbiologia de Brock; Madigan, M. T., Martinko, J. M., Bender, K. S., Buckley, D. H., Stahl, D. A., eds.; Artmed: Porto Alegre, 2016.

79. Sobek, S.; Del Sontro, T.; Wongfun, N.; Wehrli, B.; Geophys. Res. Lett. 2012, 39, L01401.

80. Guérin, F.; Abril, G.; J. Geophys Res. 2007, 112, G03006.

81. Guérin, F.; Abril, G.; Junet, A.; Bonnet, M. P.; Appl. Geochem. 2008, 23, 2272. 